ice during flights in recent years, that the land-ice round this coast is heavily crevassed and would make travelling difficult. On the other hand, he thinks that the sea-ice will give a suitable surface and that lines of stranded bergs prevent it breaking up near the coast. The experience of others in the Weddell Sea suggests that these are optimistic views, but Capt. Riiser-Larsen admits that if the route proves impracticable, journeys will be made in an easterly direction from Enderby Land, where there is much work to be done. The use of a sea-ice route will certainly allow plenty of seal-meat to be got for men and dogs, and so obviate the necessity of carrying full rations.

\section{Institution of Mechanical Engineers}

AT the annual general meeting of the Institution of Mechanical Engineers on February 17, Mr. A. E. L. Chorlton, M.P., was inducted as president and the annual report for 1932 was adopted. The total membership of the Institution is now 11,295, a net increase for the year of 134. While the numbers of associate members and graduates show considerable increases, there has been a decrease in the numbers of members and of students. During the year Sir Alfred Ewing, Sir Henry Fowler, Sir Vincent Raven, Sir J. J. Thomson and the late Mr. W. H. Patchell were elected honorary life members. The total revenue for the year was $£ 34,052$. The report refers to the work of the various research committees and also to the educational work done. Examinations for National Certificates and Diplomas in Mechanical Engineering were held in conjunction with the education departments in England, Scotland and Northern Ireland at which 2,829 candidates sat. Twenty National Diplomas (Air) in Mechanical Engineering were awarded jointly with the Board of Education and the Air Ministry to officers of the Royal Air Force on completion of the engineering course at Henlow. In addition to the meetings held at the headquarters of the Institution, full programmes were carried out by the nine provincial branches, the average attendance of members and visitors at each meeting being more than a hundred. The gifts to the Institution include a plaque modelled by F. J. Halnon and cast in steel, showing Faraday in his laboratory, the donor being Sir Robert Hadfield.

\section{Illuminated Fountains}

RECENT installations of illuminated fountains in Paris and Stockholm prove that magnificent effects can be produced in this way which fit in well with festive occasions. In the Escher-Wyss News for October an interesting technical description is given of an illuminated fountain which was constructed in the lake of Zurich for a 'lighting week'. A pontoon was moored 85 metres distant from the shore and away from the route of the steamer's. The caisson is circular in shape, its weight is 12 tons and the upper platform is ten metres in diameter. Five pump sets are arranged in the bottom of the caisson each capable of delivering $220 \mathrm{lb}$. of water per second when the motors rotate at 1,450 r.p.m., producing a total pressure head of 20 metres. They can be connected in series or parallel. The play of the water is arranged in eight different ways producing the appearance of circles, tulips, baskets, etc. With one arrangement the main water jet rises to a height of 45 metres, the whole fountain being apparently enveloped in foam. The whole of the playing waters are illuminated by thirty-two search-lights, each taking between 1,000 and 1,500 watts. The lamps are hermetically sealed in concrete casings. The entire pontoon is painted in a neutral colour so as not to form a contrast and interfere with the picture presented by the lake. The general effect of this fountain fits in very well with the shore illuminations. The work was completed in a few weeks and the fountain was set in operation on October 1, 1932.

\section{Steam, Electric and Diesel-Electric Traction}

IN a paper read before the Institution of Civil Engineers on February 21, H. W. H. Richards, electrical engineer to the London and North Eastern Railway, makes a definite comparison, both technical and financial, between steam, electric and Dieselelectric traction. The comparison is based on the existing traffic conditions of load and speed, so that it is on exactly the same basis in each case. It can be shown that the most satisfactory unit to adopt is the trailing ton-mile per annum per single track. The average traffic density for steam trains is about three million ton-miles and for electric trains which are practically confined to suburban service it is about 4.5 million ton-miles. It appears that on an average load of about fifty per cent for the complete electrification of the main lines in Great Britain, the total power of the steam turbines required for the electric service would be $\mathbf{3 \cdot 5}$ million brake horse power. If Diesel-electric service were adopted throughout, the total Diesel engine power required would be 15 million brake horse power. On the same basis, the total weight of electric tractors would amount to 850 thousand tons as compared with 1,300 thousand tons for Diesel-electric tractors. The capital costs for traffic densities ranging from 2 million to 10 million ton-miles are in all cases cheapest for steam and the costs of electric and Diesel-electric services are much the same at a traffic density of 4 million, after which electric traction becomes progressively cheaper. As regards operating costs, for main line services, including interest on capital, the cost of electric traction is lower than that of steam or Diesel-electric traction at traffic densities greater than $2 \cdot 5$ million ton-miles.

\section{Reading under Vibratory Conditions}

IN the paper on recent developments on electric lighting read by Mr. W. J. Jones to the Royal Society of Arts on November 30 and published in the Society's journal (J. Roy. Soc. Arts, vol. 81, p. 132) some novel experiments and phenomena were described in connexion with illumination. He showed a swinging pendulum with the letter $E$ printed at various points down its shaft. The speed of translation of any particular $E$ is directly proportional to its 
distance from the point of suspension. When the illumination on the pendulum was only two foot candles, the letter $E$ could only be seen about a quarter of the way down the pendulum. But when the illumination was increased to 100 foot candles the letter $E$ could be seen almost at the bottom of the pendulum. A connexion can thus be obtained between the speed of vision and illumination. Experiments were described on the effect produced by the vibration of public vehicles. When the vehicle was moving, an appreciable reduction both in the speed of reading and in visual acuity took place. Experiments made a few years ago by reading a newspaper in a train on the Bakerloo Railway when it was at rest and when it was running showed that in the former case the speed of reading was 220 words a minute and in the latter 140 words a minute. In this case the illumination was two foot candles. Tests carried out in trains and buses under similar conditions about the same time gave similar results, showing that there was an appreciable reduction in the speed of reading when the vehicle is in motion. Reading under vibratory conditions in a poor light is known to cause visual fatigue and is apt to produce headaches. We are glad to hear that in some of the London Underground railway coaches to-day, the illumination at reading level has been raised to about twenty foot candles. This automatically does much to mitigate the effects of vibration, so far as visual performance and comfort are concerned.

\section{English Folk Dance and Song Society}

THE recent amalgamation of the Folk Song Society with the English Folk Dance Society has been marked by the appearance of a new journal with the title Journal of the English Folk Dance and Song Society, under the editorship of Mr. Frank Howes. The contents of the first number are indicative of the policy which it is now considered desirable for the reorganised societies to pursue in common. The primary object which the original societies had in view was the collection and preservation of the remains of traditional songs and dances. This work now being regarded as completed, so far as can be seen, the main work of the joint society on its scientific side will be intensive comparative study of the material which has been collected. In the first issue both activities, it is true, are represented. Ten more of the forty Gaelic songs collected by Miss Lucy Broadwood twenty-five years ago are published, as well as some English folk songs and dances recently recorded. On the comparative side, Mr. A. G. Gilchrist makes an exhaustive study of the Scottish and Northumbrian ballad Lambkin, discussing its growth and origin in the light of some forty versions. Similar studies of no little interest to students of culture and of 'survivals' and their distribution are Miss Violet Alford's record of the form and distribution of the Farandole in the south of France and in Spain and the study of the sword-dance by Dr. R. Wolfram of Vienna, who connects it with the initiation ceremony, seeing in the decapitation of the 'fool' the ritual death of initiation rather than the memory of a fertility sacrifice.

\section{Sadi Carnot, I796-I832}

IN La Nature of February 1, under the title "Grandeur et Modestie d'un savant Français : Sadi Carnot", M. Roger Vène gives a sketch of the life and character of the young French engineer who wrote the famous essay "Réflexions sur la puissance motrice du feu". Carnot was only twenty-eight years of age when he published the essay, and he died of cholera eight years later. According to the regulations, the clothes and papers belonging to the victims of the cholera epidemic which swept through Paris in 1832 were to be destroyed, but fortunately some of Carnot's manuscripts were saved by his friend Clapeyron. Born in the Petit Luxembourg when his father, Lazare Carnot, was a member of the Directory, Sadi had a brilliant career as a student of the Ecole Polytechnique but was too young to take part in the Napoleonic Wars, and his life was spent mainly in the routine of the barracks. The extracts given by M. Vène reveal a charming personality. The article is accompanied by a portrait of Carnot at the age of seventeen years. An article on Carnot appeared in our columns on August 20, 1932 (p. 266).

\section{Plant Pathology at Rothamsted Experimental Station}

THE Committee of Management of the Rothamsted Experimental Station recently decided to reorganise the old Department of Mycology, started in 1918 under the charge of Dr. W. B. Brierley, now professor of agrieultural botany at the University of Reading, and to constitute it a Department of Plant Pathology with Dr. J. Henderson Smith as head. Dr. Henderson Smith studied medicine at Balliol College, Oxford, and then proceeded to the University of Edinburgh, where he took his medical degree; he was then awarded the Philip Walker studentship in pathology, which he held at Oxford until his appointment first as bacteriologist at the Lister Institute and afterwards as plant pathologist in the Mycology Department at Rothamsted. He has published numerous papers on animal pathology, especially immunity and bacteriology, and on plant pathology, especially virus diseases.

\section{Motor-Car Speed Record}

ON February 22, Sir Malcolm Campbell broke his own motor-car speed record on Daytona Beach, Florida, in his car the Blue Bird. On the southward run Sir Malcolm covered the mile in $13 \cdot 16$ sec. and in the northern run in $13.60 \mathrm{sec}$. His mean speed worked out at $272 \cdot 108$ miles per hour, thus being well ahead of his record of 253.978 miles per hour set up last year. The Blue Bird is fitted with a RollsRoyce engine developing 2,350 H.P. at 3,200 R.M.P. The engine has a bore of 6 in. and a stroke of $6 \cdot 6$ in. This type of engine was also installed in the aeroplane which won the Schneider Trophy for Great Britain and in the machine in which Flight-Lieut. Stainforth achieved the world's present air speed record of $407 \cdot 5$ miles per hour.

\section{British Fresh-Water Fishes}

THE Trustees of the British Museum have published a second edition of their "Guide to the British 